DOI 10.14746/ssp.2017.3.4

\author{
Krzysztof TOMASZEWSKI
}

Uniwersytet Warszawski

\title{
Wplyw inwestycji infrastrukturalnych w sektorze gazowym na bezpieczeństwo energetyczne Europy Środkowo-Wschodniej
}

Streszczenie: Infrastruktura energetyczna jest jednym z czynników warunkujących bezpieczeństwo energetyczne współczesnego państwa. Niniejszy artykuł dotyczy problematyki sektora gazu ziemnego i nowych inwestycji infrastrukturalnych w regionie Morza Bałtyckiego. W tekście skonfrontowano teorię procesu integracji europejskiej (zagadnienia solidarności i lojalności) z praktyką wynikającą z pragmatycznego podejścia państw członkowskich UE do problematyki bezpieczeństwa energetycznego. Zastosowanie perspektywy nauk politycznych umożliwiło kompleksową analizę konsekwencji politycznych wynikających z realizacji połączeń gazowych (Nord Stream I, Nord Stream II oraz Baltic Pipe) w regionie Europy Środkowo-Wschodniej. Artykuł prezentuje grę interesów wokół analizowanych projektów gazowych oraz wskazuje, iż są one warunkowane przede wszystkim partykularnymi interesami państw (i firm) uczestniczących w realizacji tych projektów.

Słowa kluczowe: bezpieczeństwo energetyczne, gaz ziemny, infrastruktura energetyczna, Europa Środkowo-Wschodnia, Unia Europejska

$\mathbf{P}$ roblematyka bezpieczeństwa energetycznego ma złożoną naturę. Współczesne państwa podejmują w tym zakresie zarówno działania indywidualne, jak i przedsięwzięcia zbiorowe w wymiarze ponadnarodowym. Do pierwszej kategorii, należałoby zaliczyć wszystkie samodzielne inicjatywy państwa (zwłaszcza rządu), zmierzające do zapewnienia stałego dostępu do surowców energetycznych po cenach, które są ekonomicznie uzasadnione i jednocześnie akceptowalne społecznie (Kryzia, 2016, s. 48).

Do drugiej kategorii - obejmującej wymiar ponadnarodowy - należałoby zaliczyć takie inicjatywy współpracy między państwami, które mają na celu współdziałanie w kierunku zapewnienia całemu ugrupowaniu dostępu do surowców i energii. Ten aspekt wydaje się szczególnie ważny, zwłaszcza w dobie procesów międzynarodowej integracji poli- 
tycznej i gospodarczej, które można obserwować na świecie od drugiej połowy XX wieku (Kaczmarski, 2010). Z punktu widzenia niniejszego artykułu kluczowe znaczenie ma - w szczególności - proces integracji europejskiej. Państwa Europy Środkowo-Wschodniej z powodzeniem przystąpiły do Unii, widząc w tym szansę na lepszą przyszłość polityczną i gospodarczą. Nadzieje związane z akcesją zostały spełnione, jednak w niektórych sferach można mówić o rozczarowaniu. Dotyczy to z pewnością współdziałania w obszarze polityki energetycznej i bezpieczeństwa energetycznego. Chociaż Unia Europejska deklaruje wolę współdziałania w tym zakresie, co znajduje potwierdzenie w zapisach traktatowych na temat energetyki, to w praktyce zaznacza się bardzo silny indywidualizm państw członkowskich w zakresie realizowanych celów w polityce energetycznej. Przejawia się on przede wszystkim w podejmowaniu przez państwa członkowskie takich aktywności, które mają służyć przede wszystkim bezpieczeństwu energetycznemu ich gospodarek, a nie całej Unii Europejskiej. Takie działania nie sprzyjają solidarności europejskiej, a jedynie pogłębiają rozbieżności między państwami członkowskimi i umacniają poszczególne rządy w przekonaniu, że o bezpieczeństwo energetyczne najlepiej jest troszczyć się w wymiarze indywidualnym.

Celem niniejszego artykułu jest analiza inwestycji infrastrukturalnych w regionie Morza Bałtyckiego, które mają bezpośredni wpływ na funkcjonowanie sektora gazowego i bezpieczeństwo energetyczne państw Europy Środkowo-Wschodniej. Przedmiotem badania będą - w szczególności - takie inicjatywy jak gazociąg: Nord Stream I, Nord Stream II oraz Baltic Pipe (jako część Korytarza Północ-Południe). Chodzi o to, aby zweryfikować w jakim stopniu realizacja tych projektów jest zbieżna z założeniami polityki energetycznej Unii Europejskiej oraz odpowiada interesowi wspólnotowemu, a w jakim wynika ona z partykularnych interesów państw bezpośrednio zaangażowanych w te przedsięwzięcia?

Mając na uwadze powyższe cele, należałoby postawić następującą hipotezę: projekty infrastruktury gazowej w regionie Morza Bałtyckiego nie są inspirowane solidarnością europejską, ale wynikają z partykularnych potrzeb zaangażowanych w nie stron.

Odnosząc się do literatury przedmiotu należy podkreślić, iż studia dotyczące bezpieczeństwa energetycznego Polski są bardzo często podejmowane zarówno przez środowiska reprezentujące nauki techniczne, jak i społeczne. Mając na uwadze pierwszą kategorię należy zauważyć wartościowe analizy podejmowane przez środowisko naukowe z Akademii Górniczo-Hutniczej w Krakowie. Prace realizowane przez: M. Ka- 
liskiego, S. Nagyego, J. Siemka, S. Rychlickiego, A. Szurleja stanowią znaczący wkład w zrozumienie uwarunkowań ekonomicznych sektora gazowego na tle dynamiki, jaką obserwujemy w kontekście procesu integracji europejskiej. Z punktu widzenia nauk społecznych, należałoby wskazać - dla przykładu - prace naukowe realizowane przez badaczy ze Szkoły Głównej Handlowej w Warszawie (K. Żukrowska, K. Księżopolski), Wojskowej Akademii Technicznej (P. Kwiatkiewicz) czy Uniwersytetu im. A. Mickiewicza w Poznaniu (R. Rosicki). Są one poświęcone politycznym, ekonomicznym oraz międzynarodowym uwarunkowaniom bezpieczeństwa energetycznego oraz polityki energetycznej. Z punktu widzenia analizy bieżących wydarzeń w zakresie omawianej problematyki, cenne wydają się również analizy Polskiego Instytutu Spraw Międzynarodowych (PISM) oraz Ośrodka Studiów Wschodnich (OSW).

Odnosząc się do przedmiotu badań w niniejszym artykule, należy podkreślić, iż analiza problematyki bezpieczeństwa dostaw gazu w regionie Europy Środkowo-Wschodniej wydaje szczególnie istotna w kontekście zrozumienia problemów polityki energetycznej Unii Europejskiej (Castel, 2014, s. 163-165).

Biorąc pod uwagę wymiar teoretyczny, wykorzystana zostanie metoda decyzyjna. Posłuży ona zarówno do zbadania przesłanek, jakie składają się na podejmowanie określonych decyzji w odniesieniu do projektów infrastrukturalnych, jak również skutków, które się z tym wiążą (Chodubski, 2004, s. 130). Procesy decyzyjne związane z budową nowej infrastruktury w regionie stanowią - bez wątpienia - złożony zespół powiązań przyczynowo-skutkowych. Ich wyjaśnienie pozwoli nie tylko na dokładniejsze zrozumienie rzeczywistości (Chmaj, Żmigrodzki, 1996, s. 48), ale również - w opinii autora - może wpłynąć na bardziej świadome projektowanie podobnych przedsięwzięć $\mathrm{w}$ przyszłości.

\section{Polityka energetyczna Unii Europejskiej - między solidarnością a indywidualizmem}

Zgodnie z przepisami Traktatu o funkcjonowaniu Unii Europejskiej (dalej jako: TFUE) polityka energetyczna ma na celu (TFUE, art. 194): zapewnienie funkcjonowania rynku energii, zapewnienie bezpieczeństwa dostaw energii w Unii, wspieranie efektywności energetycznej i oszczędności energii, jak również rozwoju nowych i odnawialnych form energii oraz wspieranie wzajemnych połączeń między sieciami energii. 
Mając na uwadze te zapisy można przyjąć, iż budowa oraz rozbudowa sieci energetycznych, a za takie można również uznać gazociagi, jest zjawiskiem jak najbardziej oczywistym i pożądanym z punktu widzenia prawa Unii Europejskiej. Na poparcie tej tezy można zaprezentować również przepisy TFUE, art. 170, dotyczący sieci transeuropejskich. Zapisano w nim, iż „Unia przyczynia się do ustanowienia i rozwoju sieci transeuropejskich w infrastrukturach transportu, telekomunikacji i energetyki”, aby „zrealizować cele określone w art. $26^{1}$ i $174^{2}$ oraz umożliwić obywatelom Unii, podmiotom gospodarczym, wspólnotom regionalnym i lokalnym pełne czerpanie korzyści z ustanowienia obszaru bez granic wewnętrznych". Interpretując treść art. 170 należy uznać, iż sieci transeuropejskie stanowią ważny element urzeczywistniania integracji, ponieważ przyczyniają się do tworzenia spójnej tkanki infrastrukturalnej w obrębie wskazanych dziedzin na obszarze całej Unii Europejskiej. Analiza powyższych przepisów winna zostać ponadto uzupełniona o art. 122 TFUE. Zapisana została w nim tzw. „klauzula solidarności”: „bez uszczerbku dla innych procedur przewidzianych w Traktatach, Rada na wniosek Komisji, może postanowić w duchu solidarności między państwami członkowskimi, o środkach stosownych do sytuacji gospodarczej, w szczególności w przypadku wystąpienia poważnych trudności w zaopatrzeniu w niektóre produkty, zwłaszcza w obszarze energii”. Warto podkreślić za J. Barczem (2009, s. 39), iż „klauzula solidarności w dziedzinie polityki energetycznej znalazła się w Traktacie na wniosek delegacji polskiej”. Samo pojęcie solidarności pojawia się w TFUE również w art. 194, gdzie wskazano, iż polityka energetyczna Unii Europejskiej winna być prowadzona „w duchu solidarności między państwami członkowskimi”.

Jak wskazuje M. Muszyński, solidarność w polityce międzynarodowej polega na takim ograniczaniu własnych interesów na rzecz partnera, by obie strony osiagnęły obiektywnie maksymalny zysk, a żadna z nich nie doznała nieuzasadnionej straty (Muszyński, 2015).

Pojęcie „solidarności” znane jest w polityce międzynarodowej w XX wieku, głównie w kontekście relacji gospodarczych i polityki rozwojowej. W praktyce Unii Europejskiej stanowi jednak swoistą nowość, ponieważ na przestrzeni procesu integracji podstawowe znaczenie miało przede wszystkim wypełnianie postanowień traktatowych w dobrej wierze (Steinvorth, 2017, s. 12-15). Praktyczne podejście do problemu „solidarności” jest

1 Art. 26 TFUE dotyczy rynku wewnętrznego.

2 Art. 174 TFUE odnosi się do problematyki spójności społecznej, gospodarczej i terytorialnej. 
niewątpliwie trudnym wyzwaniem (Sangiovanni, 2013), bowiem, zgodnie $\mathrm{z}$ teorią realizmu międzynarodowego, każde państwo zmierza przede wszystkim do maksymalizowania własnych dążeń i osiaggania partykularnych interesów (Czaputowicz, 2008, s. 71). Tymczasem, jak pisze M. Muszyński, traktatowa formuła solidarności europejskiej faktycznie ma w swej istocie element poświęcenia własnych interesów na rzecz partnerów.

Oprócz solidarności, podstawową zasada, na której opiera się Unia Europejska, jest zasada lojalnej współpracy, zapisana w Traktacie o Unii Europejskiej (dalej jako: TUE). W jego art. 2 określono, iż „Unia i Państwa Członkowskie wzajemnie się szanują i udzielają sobie wzajemnego wsparcia w wykonywaniu zadań wynikających z Traktatów". Sukces procesu integracji uzależniony jest więc od efektywnej współpracy podmiotów zaangażowanych w budowanie Unii Europejskiej. Lojalna współpraca winna być swoistą „dyrektywą” dla państw członkowskich oraz instytucji, aby w podejmowanych przedsięwzięciach kierowały się wzajemnym szacunkiem, co oznacza jednocześnie zaniechanie działań, które mogłyby być uznane za niekorzystne lub wrogie przez pozostałych partnerów współpracy europejskiej.

Mając na uwadze powyższe uwarunkowania teoretyczno-prawne, należy zauważyć, iż istnieją wszelkie niezbędne prawne przesłanki do efektywnego realizowania polityki energetycznej, opartej na zasadach solidarności oraz lojalności. Z instytucjonalnego punktu widzenia należy dodać, iż na poziomie ponadnarodowym (instytucje UE), jak również narodowym (rządy, agencje rządowe, urzędy regulacyjne) istnieją odpowiednie struktury, które umożliwiają implementowanie celów polityki energetycznej, zgodnie z postanowieniami traktatów europejskich (Tomaszewski, 2014, s. 211).

W praktyce Unii Europejskiej nie jest jednak łatwo stosować się do opisanych zasad, co przekłada się negatywnie na tempo realizacji zadań polityki energetycznej. Państwa członkowskie kierują się raczej przesłankami związanymi z ochroną interesów narodowych, aniżeli wytycznymi traktatów. O ile bowiem interes narodowy łatwo jest określić (przynajmniej w kategoriach najbliższego horyzontu wyborczego), o tyle interes wspólnotowy czy „solidarność” europejską zdefiniować jest niezwykle trudno. Tym bardziej, iż Unia Europejska en bloc - jako organizacja międzynarodowa - postrzegana jest w państwach członkowskich w sposób niejednokrotnie bardzo instrumentalny.

Jak wskazuje V. Schmidt (2010, s. 334) posiedzenia Rady nie są transmitowane w mediach. Politycy uczestniczący w spotkaniu mogą więc prezentować inne stanowisko na forum Rady, kiedy poszukują porozumienia z pozostałymi uczestnikami spotkania, a inne - swoim obywate- 
lom po powrocie do kraju. Kiedy więc delegacja osiagnie sukces, ponieważ ostateczne stanowisko UE jest zbieżne $\mathrm{z}$ wyjściowym stanowiskiem narodowym, można wskazywać, iż rządzący wiele zrobili, aby zadbać o losy kraju i obywateli. Unia jawi się wówczas, jako sojusz korzystny dla obywateli, a ekipa rządząca zyskuje zaufanie społeczeństwa. Kiedy jednak decyzja UE jest niekorzystna w stosunku do wyjściowego stanowiska krajowego, wówczas politycy mogą tłumaczyć, że chociaż podjęli wszelkie możliwe kroki, aby zadbać o interes narodowy, większość krajów przesądziła inaczej. W tym ujęciu, Unia Europejska będzie przedstawiana w negatywnym świetle, jako sojusz, który narzuca państwom członkowskim swój dyktat i zobowiązuje poszczególne delegacje do przyjęcia rozwiązań, które nie są korzystne dla obywateli danego państwa. Wizja Unii Europejskiej prezentowana przez krajowych polityków zależy więc w dużej mierze od ich sukcesów bądź porażek negocjacyjnych na forum wspólnotowym (Tömmel, 2009, s. 9-11).

Przedstawione powyżej problemy systemowe nie są jedynymi, które utrudniają w praktyce efektywną realizację polityki energetycznej i poszanowanie zasad lojalności i solidarności energetycznej. Dodatkowymi przeszkodami na drodze skutecznej współpracy mogą być także przyczyny o charakterze strukturalnym, wynikające ze zróżnicowania gospodarczego państw członkowskich (Vivid Economic, 2016, s. 18), a mianowicie:

- różnice w sposobie postrzegania przez państwa członkowskie znaczenia sektora energetycznego w gospodarce narodowej;

- odmienne bilanse energetyczne, w zależności od poziomu rozwoju gospodarczego oraz przyjętej struktury wytwarzania energii;

- różny poziom uzależnienia państw członkowskich od zewnętrznych (pozaeuropejskich) dostaw surowców energetycznych (w szczególności gazu ziemnego);

- specyfika połączeń infrastrukturalnych między poszczególnymi państwami członkowskimi (położenie wzdłuż kluczowych linii przesyłowych lub peryferyjnie) (Komisja Europejska, 2010a).

Te wszystkie czynniki przesądzają o tym, iż o wspólnej polityce energetycznej łatwiej jest mówić, aniżeli realizować ją w praktyce.

\section{Infrastruktura gazowa - projekty niezgody}

Niniejszy tekst dotyczy Europy Środkowo-Wschodniej. Ważne jest więc ustalenie specyfiki tego regionu w kontekście problematyki bezpie- 
czeństwa energetycznego. Tym, co charakteryzuje omawiany obszar jest silne uzależnienie dostaw gazu ziemnego do państw tego regionu od jednego dostawcy. Jest nim Federacja Rosyjska.

\section{Mapa 1. Infrastruktura przesylowa gazu ziemnego z Federacji Rosyjskiej}

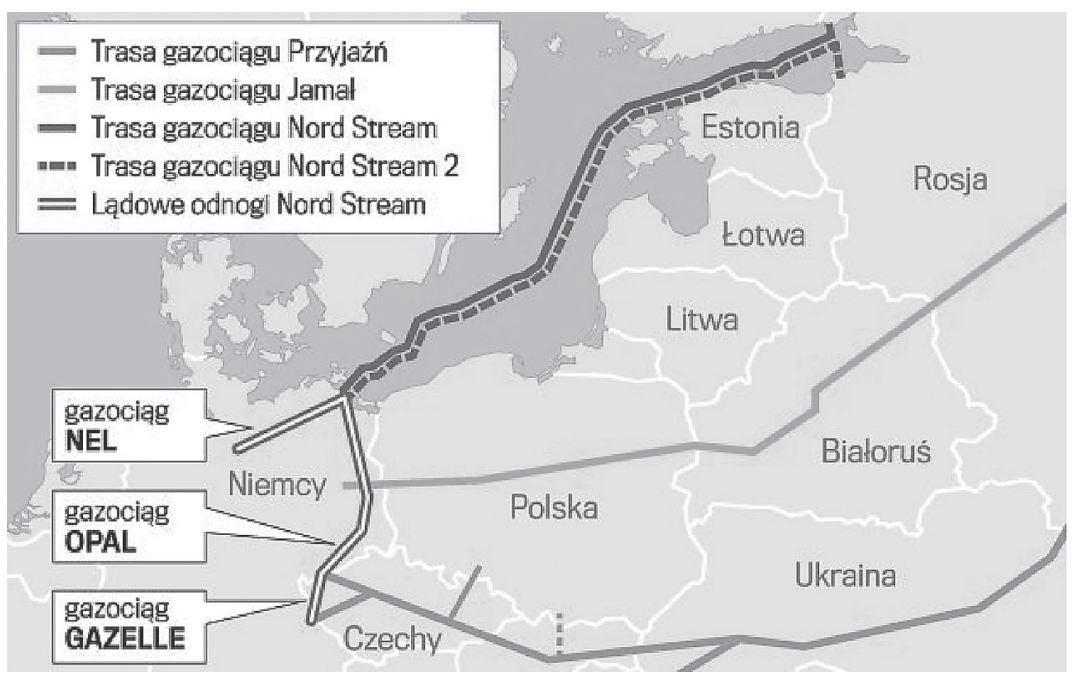

Źródło: GW, Nord Stream, 2017.

Taka sytuacja jest efektem wieloletniego kształtowania relacji gospodarczych i politycznych państw tego regionu, na podstawie ładu politycznego ustalonego po II wojnie światowej. Silne uzależnienie od ZSRR wywarło znaczący wpływ na systemy gospodarcze omawianych państw. Wraz z dekonstrukcją żelaznej kurtyny państwa Europy Środkowo-Wschodniej obrały kierunek integracji ze strukturami Wspólnot Europejskich. O ile relacje handlowe zostały głęboko przekształcone, co wynikało niejako z logiki procesów integracyjnych, o tyle istniejąca infrastruktura energetyczna przetrwała zmiany polityczne i tak, jak w czasach RWPG była symbolem współpracy państw bloku socjalistycznego, tak w nowych warunkach stała się ona poważnym obciążeniem. Sojusze polityczne i gospodarcze zmienily się zdecydowanie, natomiast struktura dostaw surowców energetycznych pozostała niezmieniona. W konsekwencji, głównym dostawcą surowca do państw Europy ŚrodkowoWschodniej, należących współcześnie do UE nadal pozostaje Federacja Rosyjska - państwo, dla którego surowce energetyczne nie są jedynie 
czynnikiem gromadzenia bogactwa narodowego, ale stanowią - przede wszystkim - instrument oddziaływania międzynarodowego.

Tego typu percepcja Federacji Rosyjskiej - mająca swoje głębokie uzasadnienie historyczne - jest immanentnie zakodowana w sposobie myślenia państw dawnego bloku socjalistycznego. Jednak taka narracja jest zupełnie niezrozumiała i niepodzielana przez przywódców państw Europy Zachodniej. Dla nich dostawy gazu z Federacji Rosyjskiej stanowią ważne, jeśli nie kluczowe, źródło zaopatrzenia w ten surowiec, aczkolwiek reprezentują jeden z kierunków dostaw, obok dostaw z państw Bliskiego Wschodu czy z Norwegii, nie licząc dostaw gazu w postaci LNG od eksporterów z pozostałych stron świata. Gaz rosyjski jest więc postrzegany w kategoriach - surowca taniego i łatwo dostępnego (głównie ze względu na już istniejącą infrastrukturę przesyłowa), a Federacja Rosyjska jawi się - co sami Rosjanie w swojej narracji powtarzają - jako pewny i przewidywalny partner handlowy, który pragnie jedynie uczciwie zarabiać na dostawach gazu do Europy (Demkowicz, 2010). Od stopnia zdywersyfikowania struktury dostaw jest - w konsekwencji - uzależniona cena gazu na krajowych rynkach (Szurlej, 2008, s. 328; Vivid Economics, 2016, s. 31).

\section{Wykres 1. Różnice w cenach gazu ziemnego w wybranych państwach UE} (okres: 2013-2014)

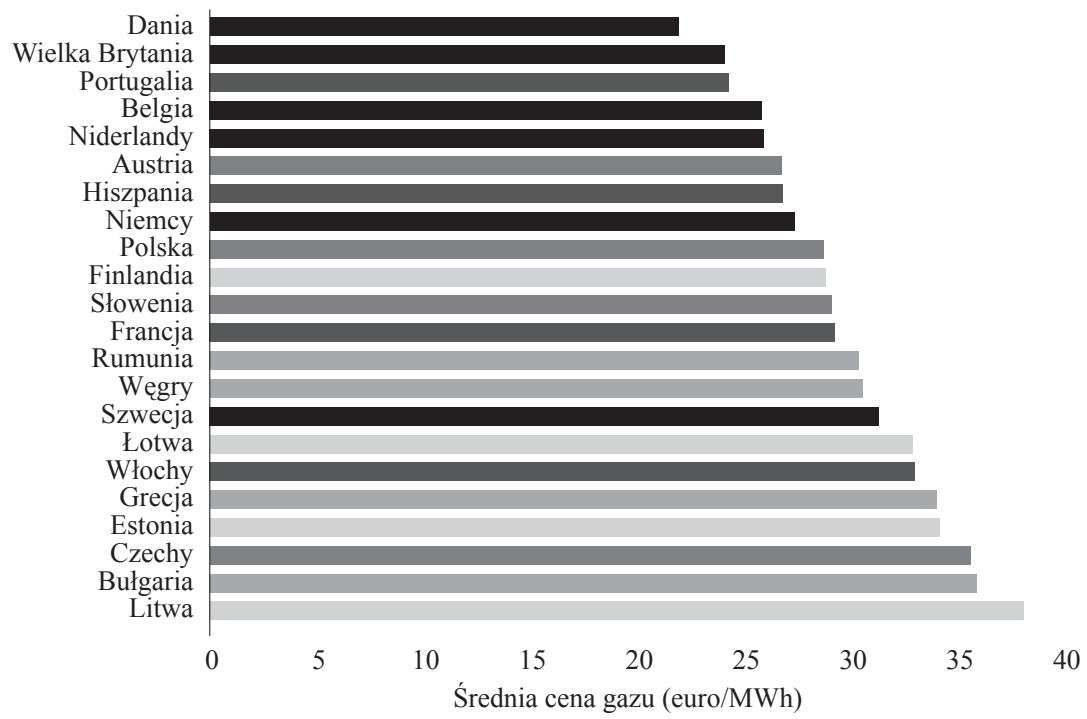

Źródlo: EA, Eurostat, Platts data 2016 (za: Vivid Economics, 2016, s. 36). 
Rozbieżności między Wschodem i Zachodem w sposobie postrzegania Federacji Rosyjskiej, jako dostawcy gazu do Unii Europejskiej zostały dostrzeżone przez Komisję Europejską. Kształtując podstawy wspólnej polityki energetycznej, wielokrotnie akcentowała ona potrzebę „dywersyfikacji kierunków i dróg dostaw surowców energetycznych” do państw członkowskich (Komisja Europejska, 2000). Ten postulat był również jednym z filarów strategii na rzecz poprawy bezpieczeństwa energetycznego UE.

Nie przeszkadza to jednak państwom członkowskim przejawiać własną inicjatywę w zakresie budowania połączeń gazowych czy - generalnie rzecz biorąc - rozbudowywania narodowej infrastruktury energetycznej. Jak wskazano wcześniej, interes narodowy okazuje się znacznie silniejszym bodźcem do działania w tym zakresie, aniżeli unijne zalecenia. Doskonałymi przykładami obrazującymi powyższe twierdzenie są wspomniane wcześniej projekty gazociagów: Nord Stream I, Nord Stream II oraz Baltic Pipe.

Dwa pierwsze gazociągi stanowią ważny element budowania połączeń transeuropejskich na trasie: Federacja Rosyjska - Niemcy. Trzeci gazociąg jest natomiast projektem połączenia Europy Środkowo-Wschodniej z norweskimi złożami surowcowymi. Mając na uwadze założenia badawcze niniejszego tekstu, należy zastanowić się nad potencjalnymi konsekwencjami wynikającymi z istnienia (lub planowanej budowy) tych połączeń.

Pierwszym z projektów, który znacząco poróżnił państwa Unii Europejskiej był bez wątpienia gazociąg Nord Stream I. Umowę ws. budowy tego połączenia zainteresowane strony zawarły we wrześniu 2005 roku. Była to inicjatywa spółek: OAO Gazprom, BASF AG oraz E.ON AG. Dla realizacji wspólnego przedsięwzięcia powołały one spółkę North European Gas Pipeline Company. W roku 2006 nazwę przemianowano na Nord Stream AG (2012, s. 11). Rosyjski Gazprom objął 51\% udziałów w projekcie, dzięki czemu sprawuje pełną kontrolę nad gazociągiem. BASF poprzez należącą do niej spółkę Wintershall Holding AG kontroluje $20 \%$ akcji, podobnie zresztą jak E.ON poprzez swoją E.ON Ruhrgas AG. Ponadto 9\% udziałów znalazło się w portfelu Gasunie Infrastruktur AG, należącej do N.V. Nederlandse Gasunie (Nord Stream, 2012, s. 8). Aktualny poziom udziałów poszczególnych spółek prezentuje poniższy wykres.

Projekt od samego początku wzbudzał wiele kontrowersji (Nagy, Rychlicki, Siemek, 2009, s. 418). Teoretycznie stanowił realną formę zabez- 


\section{Wykres 2. Udziały firm w gazociągu Nord Stream (stan na 2017 rok)}

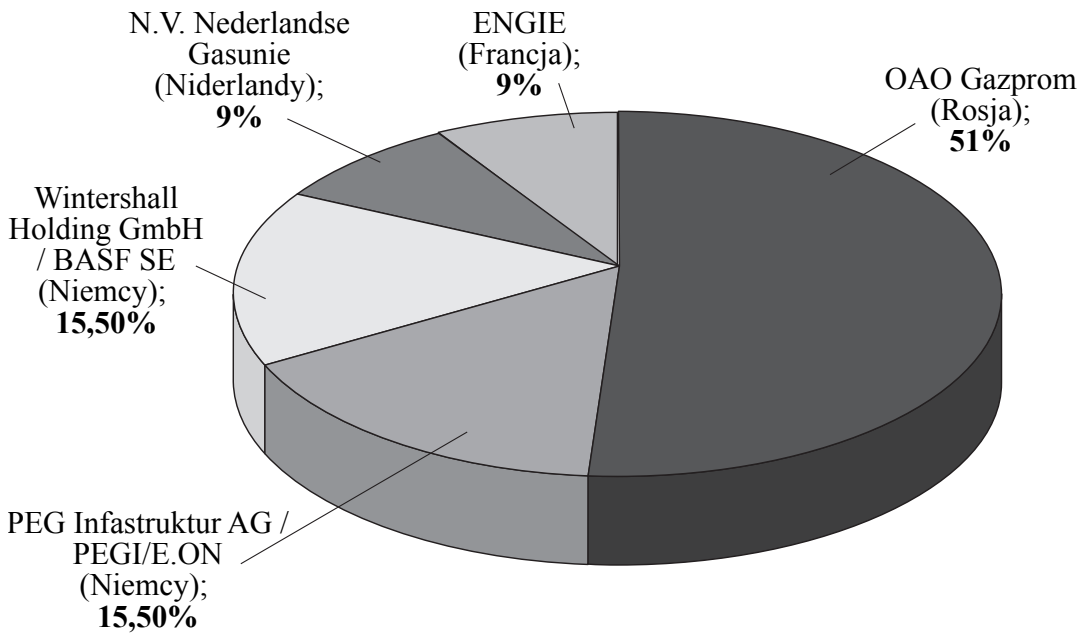

Źródło: Opracowanie własne na podstawie: Nord Stream, 2017.

pieczenia dostaw gazu ziemnego do Unii Europejskiej, z drugiej jednak strony zasadniczo uzależniał państwa korzystające z tego połączenia od dostaw rosyjskiego gazu, a ponadto całkowicie pomijał dotychczasowe państwa tranzytowe (Polskę, Ukrainę, Białoruś). Jednoznaczna ocena projektu nie jest łatwa. Spółka realizująca projekt, czyli Nord Stream AG, prezentowała go jako ekologiczne i ekonomicznie uzasadnione przedsięwzięcie, które na dziesiątki lat zapewni UE dostawy gazu ziemnego (Nord Stream, 2012, s. 207). Odmiennie budowę Nord Stream postrzegali jego przeciwnicy, który wskazywali przede wszystkim, iż projekt ma charakter polityczny, zagraża bezpieczeństwu ekologicznemu Bałtyku oraz jest nieracjonalny ekonomicznie.

Realizacja budowy spowodowała, iż państwa członkowskie UE podzieliły się na dwa spolaryzowane stronnictwa. Po jednej stronie znaleźli się beneficjenci projektu, czyli rządy oraz przedsiębiorstwa z tych państw, które były zaangażowane w przedsięwzięcie (przede wszystkim: Niemcy, Francja, Niderlandy oraz - spoza UE - Rosja ), po przeciwnej stronie były te państwa, które uznawały, że Nord Stream stanowi poważne zagrożenie dla ich interesów narodowych (Polska, Szwecja, Dania, Finlandia, Litwa, Łotwa, Estonia), a nawet dla interesu europejskiego, ponieważ wskazywano, iż jego realizacja spowoduje wzrost cen gazu dla 
odbiorców w Unii Europejskiej. Każda ze stron szermowała argumentami o charakterze politycznym, ekonomicznym i społecznym. Do sporu włączył się Parlament Europejski, na forum którego deputowani z zaangażowanych w projekt krajów toczyli intensywne debaty. Różnice zdań uniemożliwiły jednak wypracowanie jednoznacznego stanowiska w tej sprawie.

Ostatecznie zwolennicy projektu zwyciężyli. Nord Stream I został oddany do użytku w 2011 roku. Czy można mówić o sukcesie w przypadku tej inwestycji? Z punktu widzenia państw i firm zaangażowanych $\mathrm{w}$ realizację tego przedsięwzięcia jest to z pewnością sukces. Nowa trasa transportu gazu rosyjskiego do Unii Europejskiej została uruchomiona i oddana do użytku. Przepustowość dwóch nitek nowego gazociagu razem stanowi $55 \mathrm{mld}^{3}$ gazu rocznie (po 27,5 $\mathrm{mld} \mathrm{m}^{3}$ na każdą rurę przesyłową).

Z perspektywy państw, które usiłowały zablokować projekt, jego realizacja stanowi niewątpliwą porażkę. Doszło bowiem do bezprecedensowej sytuacji, która jasno pokazała, że w obliczu rozbieżnych interesów państw członkowskich nie można liczyć na obiektywizm Komisji Europejskiej, ani efektywne wsparcie pozostałych instytucji, które uniemożliwiłyby realizację projektów infrastrukturalnych naruszających interesy polityczne i ekonomiczne pozostałych partnerów.

Nord Stream I był projektem przełomowym nie tylko dlatego, iż była to pierwsza tego typu realizacja w rejonie Morza Bałtyckiego, ale również była ona swoistym precedensem w historii projektów infrastrukturalnych Unii Europejskiej. Jedynym rzeczywistym beneficjentem okazała się Federacja Rosyjska, ponieważ Nord Stream I pozwolił zabezpieczyć pozycję rosyjskiego gazu ziemnego na europejskim rynku surowcowym, a ponadto zapewnił stabilne dostawy surowca rosyjskiego do Europy Zachodniej, pozwalając uniknąc problemu „niepewnych” - z punktu widzenia Rosjan - krajów tranzytowych (takich jak: Białoruś, Ukraina, Polska) (Kochanek, 2015, s. 223).

Z punktu widzenia UE, można go uznać za przykład mitologicznego ,jabłka niezgody”, które skutecznie poróżniło państwa członkowskie. Należałoby zastanowić się, czy ekonomiczne korzyści z tytułu tej budowy są większe aniżeli polityczne straty, związane przede wszystkim poczuciem braku lojalności między państwami członkowskimi? Nord Stream I mógł okazać się dla Unii Europejskiej ważnym doświadczeniem wskazującym, iż brak solidarności oraz lojalności w realizowaniu projektów infrastrukturalnych prowadzi do rozdźwięku między państwami 
członkowskimi i utrudnia efektywne realizowanie polityki energetycznej Unii Europejskiej. Tak się jednak nie stało i w roku 2015 pojawiła się ponownie koncepcja budowania gazociągu łączącego Federację Rosyjską i Niemcy - Nord Stream II. Podobnie jak w przypadku projektu z 2005 roku akcjonariusze powołali do życia spółkę celową - Nord Stream 2 AG z siedzibą w Szwajcarii. Dominująca rola w projekcie po raz kolejny przypadła firmie OAO Gazprom. Jej partnerami zostały spółki: Wintershall Nederland B.V., Uniper Global Commodities SE, OMV Nord Stream II Holding AG, Shell Exploration and Production B.V. oraz Engie $\mathrm{SA}^{3}$. Planowane koszty projektu oszacowano na ok. 9,9 mld euro. Morski odcinek Nord Stream II, liczący 1224 km, ma zaczynać się od tłoczni Portowaja koło Wyborga, a kończyć w okolicach Greifswaldu. Będzie przebiegał przez wody terytorialne bądź wyłączne strefy ekonomiczne Rosji, Finlandii, Szwecji, Danii i Niemiec (Nord Stream 2, 2017, s. 6). Po stronie rosyjskiej nowe nitki mają się zaczynać w rejonie Ust-Ługi w obwodzie leningradzkim. Trasa nowych dwóch nitek rurociągu biegnie po dnie Morza Bałtyckiego równolegle do obecnie istniejącej infrastruktury. Przepustowość nowego rurociagu (dwóch jego nitek) wynosić będzie podobnie jak dwóch pierwszych 27,5 $\mathrm{mld}^{3}$ gazu rocznie. Oznacza to, iż zdolności przesyłowe Nord Stream II będą się kształtowały się na poziomie $55 \mathrm{mld} \mathrm{m}^{3}$ gazu ziemnego, a cała infrastruktura obydwu gazociągów na dnie Bałtyku będzie się cechowała przepustowością rzędu $110 \mathrm{mld} \mathrm{m}^{3}$. Takie rozwiązanie pozwoli Rosji na całkowite uniezależnienie się od lądowej infrastruktury przesyłowej. Będzie mogła tym samym ograniczać dostawy gazociągami biegnącymi przez Ukrainę i używać gazu jako narzędzia nacisku ekonomicznego wobec całej Europy Środkowo-Wschodniej (Kaliski i in., 2015, s. 66). Według przewidywań spółki projekt ma zostać ukończony do 2019 roku (Nord Stream 2, 2017).

Podobnie, jak Nord Stream I, także ten projekt dzieli państwa europejskie. Polska może stracić status państwa tranzytowego, jeśli Rosjanie będą przesyłać surowiec tylko drogą morską, Ukraina - podobnie z pań-

3 Pierwotnie ustalono następujące wpływy w konsorcjum: Gazprom - 50\% udziałów, pozostali: Engie, OMV, Shell, Uniper i Wintershall - każda firma po 10\% udziałów. Jednak po negatywnej opinii polskiego UOKiK (z lipca 2016 roku) w sprawie zgodności z prawem konkurencji transakcji objęcia udziałów w konsorcjum przez firmy zachodnioeuropejskie, zrezygnowały one $\mathrm{z}$ formalnego nabywania udziałów w spółce Nord Stream 2. UOKiK uznał, że uczestnictwo pięciu firm, działających także na polskim rynku, w jednej spółce może spowodować pogorszenie warunków konkurencji na rynku gazu w Polsce (UOKiK, 2016). 
stwa tranzytowego, może stać się zakładnikiem rosyjskiej polityki gazowej. Dania i Państwa Bałtyckie zgłaszają obawy, że Rosja wykorzysta budowę gazociagu do instalacji infrastruktury komunikacyjnej o przeznaczeniu wojskowym.

Z punktu widzenia Niemiec, Francji, Niderlandów bezpośrednio zaangażowanych w projekt, wydaje się on korzystnym rozwiązaniem - zwiększa się bowiem możliwość transportu gazu rosyjskiego do tych krajów. Skutkiem ubocznym jest jednak większa zależność od dostaw surowca z jednego kierunku. Należy dodać, że na mocy kontraktu, zatwierdzonego przez KE w 2013 roku, Rosja zwiększyła do 100\% swoje udziały w firmach zajmujących się sprzedażą oraz magazynowaniem gazu w UE - Wingas, WIEH oraz WIEE. Podmioty, których akcje są w posiadaniu Gazpromu kontroluja ponad 20\% niemieckiego rynku gazu (magazyny w Rehden, Jemgum i Haidach. Dwa pierwsze, o pojemności 4,4 mld $\mathrm{m}^{3}$ oraz 1,2 mld $\mathrm{m}^{3}$, zostały zlokalizowane w północnej części RFN, co czyni je niezwykle cennymi z punktu widzenia transportu gazu przez rurociagg Nord Stream. Trzeci natomiast znajduje się na terytorium Austrii i może pomieścić ok. 2,7 $\mathrm{mld} \mathrm{m}^{3}$ gazu).

Ponadto $\mathrm{w}$ grę wchodzi sprawa gazociagu OPAL. Stanowi on na wschodzie Niemiec odcinek lądowy gazociagu Nord Stream I (zob. mapa 1). Gazociagg ten, oddany do eksploatacji w 2011 r., łączy miejscowość Lubmin położoną koło Greifswaldu w Niemczech z miejscowością Brandov w Republice Czeskiej. Eksploatacja tego gazociagu podlega kontroli niemieckiej agencji federalnej do spraw sieci. Głównymi udziałowcami rurociagu są dwa niemieckie koncerny: Wingas $(80 \%)$ i E.ON Ruhrgas (20\%).

W październiku 2016 roku Komisja Europejska wydała decyzję o udostępnieniu Gazpromowi 80\% mocy przesyłowych gazociagu OPAL, czyli de facto wyłączenia go spod zasady TPA, stanowiącej jeden z filarów rynku energii w UE (Kamiński i in., 2015, s. 27-29). Strona polska (Rząd Rzeczypospolitej Polskiej, PGNiG oraz PGNiG Supply and Trading) wniosła skargę do Trybunału Sprawiedliwości UE w celu stwierdzenia jej nieważności. Wnioskowano także do prezesa sądu o zawieszenie wykonania decyzji KE do momentu wydania wyroków. Argumentowano, że realizacja decyzji Komisji wiąże się poważnymi i nieodwracalnymi szkodami oraz stanowi zagrożenie dla dostaw gazu do Polski. Trybunał początkowo przychylił się do tego wniosku - w grudniu 2016 roku tymczasowo zawiesił decyzję Komisji. Jednak w lipcu 2017 roku prezes Trybunału uznał, że stronie polskiej nie udało się wykazać nieuchronności 
ponoszonej szkody (Sprawa T-883/16R). W rezultacie decyzja Komisji ma charakter obowiązujący do czasu wydania ostatecznego postanowienia Trybunału.

Według szacunku ekspertów rynkowych, jeśli decyzja Komisji zostanie podtrzymana, tranzyt gazu przez Ukrainę zmniejszy się w skali roku o 20\%, generując dla tamtejszej gospodarki straty rzędu $400 \mathrm{mln}$ dolarów (Kajmowicz, 2017). Taka sytuacja będzie oznaczała w konsekwencji możliwość ograniczeń gazu także dla pozostałych krajów Europy Środkowo-Wschodniej, co miało już miejsce w przeszłości podczas rosyjskoukraińskiego konfliktu gazowego w roku 2009 (Dąbrowski, 2014, s. 8). Bezpośrednim skutkiem zwiększenia wykorzystania OPAL jest wzmocnienie roli Czech w tranzycie rosyjskiego gazu, częściowo kosztem Słowacji. Zdecydowanie spada znaczenie Ukrainy jako korytarza tranzytu gazu do UE. Szlak ukraiński w coraz większym stopniu wykorzystywany jest jako tzw. last resort option w przypadku szczytowego zapotrzebowania na gaz i braku dostępu do alternatywnych tras eksportowych. Decyzja KE oznacza również wzmocnienie roli Niemiec, a w szczególności obszaru rynkowego Gaspool, w handlu gazem w UE oraz w Europie Środkowo-Wschodniej. W opinii Komisji jednym z dobroczynnych skutków jej decyzji jest właśnie zwiększanie integracji rynku czeskiego z obszarem Gaspool. Tym samym pośrednio decyzja KE ogranicza jeszcze bardziej możliwości realizacji alternatywnych projektów integracji regionalnej (np. w ramach V4) (Loskot-Strachota, 2017).

Konkludując powyższe, budowa gazociągów Nord Stream I oraz Nord Stream II pozornie korzystna dla UE, ponieważ zabezpiecza dostawy taniego rosyjskiego gazu, w rzeczywistości pogłębia uzależnienie UE od jednego dostawcy, ponadto poważnie polaryzuje państwa członkowskie, które zupełnie odmiennie widzą kwestie bezpieczeństwa energetycznego i rosyjskiego gazu, a nadto zwiększa obecność rosyjskiego monopolisty na gazowym rynku Unii Europejskiej.

Remedium na te problemy miałaby być realizacja projektu Baltic Pipe, mocno wspieranego przez Polskę gazociagu, stanowiącego część Korytarza Północ-Południe. Projekt Baltic Pipe - jak wskazuje polski operator systemu przesyłowego Gaz System (2017) - jest strategicznym projektem infrastrukturalnym mającym na celu utworzenie nowego korytarza dostaw gazu na europejskim rynku. Umożliwi on, po raz pierwszy w historii, przesyłanie gazu bezpośrednio ze złóż zlokalizowanych w Norwegii na rynki w Danii i w Polsce, a także do odbiorców w sąsiednich krajach. 
Korytarz Północ-Południe miałby połączyć Terminal LNG w Świnoujściu oraz Gazociąg Baltic Pipe, przez południową Polskę, Republikę Czeską, Słowację i Węgry z proponowanym terminalem Adria LNG w Chorwacji.

\section{Mapa 2. Korytarz Północ-Południe (komponenty składowe projektu)}

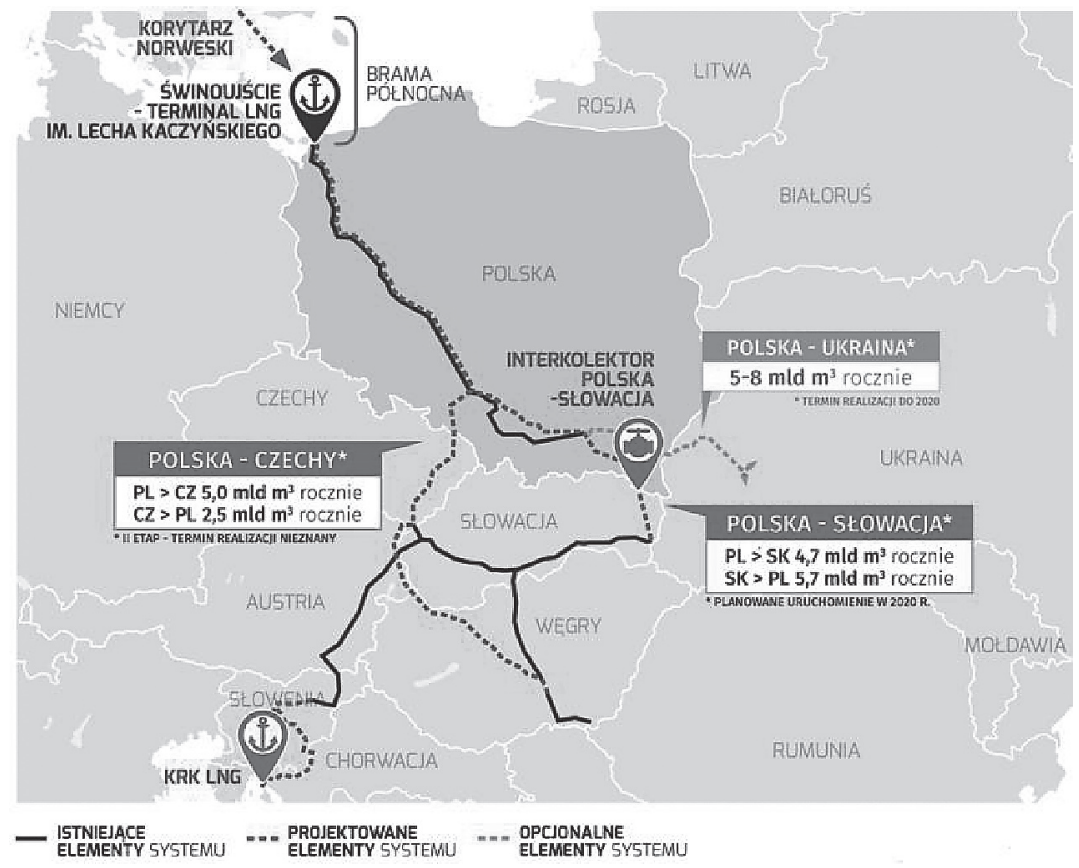

Źródło: Biznes Alert, 2017

Korytarz składałby się z wielu dwustronnych międzysystemowych połączeń gazowych oraz krajowych gazociągów, które już istnieją lub są na różnych etapach. Wśród potencjalnych korzyści tego przedsięwzięcia wymienia się: zwiększenie integracji regionalnych rynków gazu, zwiększenie bezpieczeństwa dostaw, umożliwienie dostępu do nowych źródeł dostaw (LNG, Norwegia) dla Europy Wschodniej, koordynację regionalnych projektów infrastrukturalnych, harmonizację zasad obowiązujących na rynku, umożliwienie wdrożenia regionalnych procedur prewencyjnych i awaryjnych w przypadku sytuacji kryzysowych (Gaz System, 2017). 
Komisja Europejska w październiku 2013 roku przyznała inwestycji status ,projektu o znaczeniu wspólnotowym”4 („Project of Common Interest”) (Komisja Europejska, 2013, nr 1391). Po spełnieniu dodatkowych wymagań możliwe będzie również przyznanie unijnego dofinansowania w ramach instrumentu Connecting Europe Facility ${ }^{5}$ (Parlament Europejski, Rada, 2013).

Uruchomienie w Europie Środkowej gazowego korytarza Północ-Południe mogłoby doprowadzić do geopolitycznego przełomu w całym regionie (Boromisa, Kałan, 2013, s. 37). Realizacja tego projektu oznaczałaby, iż powstałby w regionie stosunkowo jednolity rynek gazu z wysoką odpornością na zawirowania rosyjskiej polityki.

Projekt Korytarza Północ-Południe jest w trakcie rozbudowy. Należy jednak mieć na uwadze, że jego sukces jest w dużej mierze uzależniony od wszystkich państw, które partycypują w tym przedsięwzięciu. Państwa Grupy Wyszehradzkiej, które projekt zainicjowały różnią się wprawdzie narodowymi strategiami energetycznymi, zwłaszcza w zakresie planów liberalizowania rynku gazu, a ponadto mają własne lokalne priorytety w budowie infrastruktury. Jednak ich wspólnym deklarowanym celem jest dywersyfikacja dostawców i dróg dostaw gazu, co pozwoliłoby na większą niezależność energetyczną.

Poważnym problemem Europy Środkowo-Wschodniej pozostaje to, iż nie ma możliwości prowadzenia transgranicznego handlu gazem (Mickiewicz, Sokołowska, 2010). Wynika to z faktu, iż główne gazociągi przebiegają ze wschodu na zachód i nie ma między nimi połączeń. Korytarz mógłby maksymalnie wykorzystać istniejące sieci. Jednak wymagałoby to budowy kilku interkonektorów, łączących sieci gazowe poszczególnych krajów (Olkuski i in., 2015, s. 13). W ostatnich latach można zaobserwować pozytywne zmiany w tej dziedzinie. Przykładem udanej współpracy regionalnej jest połączenie gazowe między Węgrami a Rumunią, Chorwacją i Słowacją. Interkonektor gazowy Polska-Czechy

4 Projekty o znaczeniu wspólnotowym mają szczególne znaczenie dla poprawy bezpieczeństwa energetycznego i zwiększenia dywersyfikacji dostaw gazu ziemnego w Europie oraz budowy zintegrowanego i konkurencyjnego rynku.

${ }^{5}$ Connecting Europe Facility - jest instrumentem finansowym Unii Europejskiej, który zastapił program TEN-T. Wspiera rozwój trzech obszarów - sieci transportowej, energetycznej oraz telekomunikacyjnej. Unia Europejska przeznaczyła w swoim budżecie na ten cel odrębną pulę środków finansowych. Fundusze mogą być wykorzystywane w latach 2014-2020 na inwestycje dotyczące budowy i modernizacji infrastruktury w dziedzinie transportu, energetyki i telekomunikacji. 
działa od $2011 \mathrm{r}$. i będzie rozbudowywany w kolejnych latach ${ }^{6}$. W okresie 2018-2020 r. będą prowadzone prace związane z realizacją nowego interkonektora Polska-Słowacja?

\section{Mapa 3. Planowany intekonektor gazowy: Polska-Slowacja}

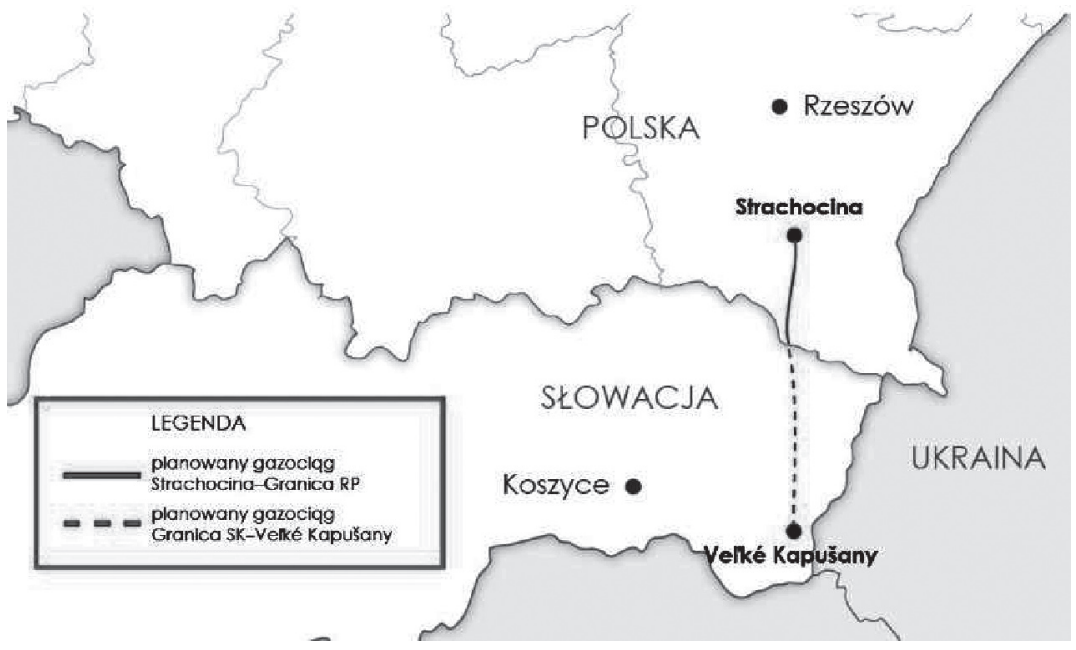

Źródlo: Gaz System S.A. 2017.

Kluczowa dla podniesienia poziomu bezpieczeństwa w sektorze gazowym jest ponadto intensywna rozbudowa magazynów, a także włączanie do współdziałania nowych partnerów, jak na przykład Rumunia. Ma ona znaczącą sieć tranzytowa, potencjalnie duże możliwości magazynowe oraz szacowane wysoko własne zasoby gazu w łupkach (Nutu, 2013, s. 41). Przy niewielkich nakładach finansowych Rumunia mogłaby wnieść bardzo

${ }^{6}$ Połączenie to jest rozbudowywane od roku 2015. Zgodnie z informacją spółki Gaz System S.A. (stan na dzień: 14.12.2017), realizuje ona wspólnie z czeskim operatorem systemu przesyłowego NET4GAS s.r.o projekt polegający na zwiększeniu zdolności przesyłowej połączenia międzysystemowego Polska-Czechy. Jego realizacja umożliwi przesyłanie większych ilości gazu w kierunku Polski oraz możliwość odwróconego przepływu, tj. z Polski do Czech.

7 Zgodnie z informacją spółki (stan na dzień: 14.12.2017) Gaz System S.A. w dniu 28 kwietnia 2017 r. Regionalny Dyrektor Ochrony Środowiska w Rzeszowie wydał Decyzję o środowiskowych uwarunkowaniach dla realizacji przedsięwzięcia pn. „Budowa międzysystemowego gazociagu stanowiqcego połaczenie systemów przesyłowych Rzeczpospolitej Polskiej i Republiki Stowackiej wraz z infrastruktura niezbędnq do jego obstugi-gazociag Strachocina-Granica RP”. 
duży wkład do działań na rzecz poprawy bezpieczeństwa energetycznego Europy Środkowo-Wschodniej. Dotyczy to w szczególności budowy interkonektorów z Bułgarią i Mołdawią oraz uruchomienia możliwości tłoczenia gazu w obie strony na jednokierunkowym połączeniu z Węgrami.

Z perspektywy politycznej, projekt Korytarza Północ-Południe nie jest tak kontrowersyjny jak projekty Nord Stream I czy Nord Stream II. Z pewnością niezadowolenie z realizacji tej koncepcji może prezentować Rosja, dla której inicjatywa państw Europy Środkowo-Wschodniej podejmowana na rzecz dywersyfikacji może być świadectwem emancypacji politycznej tego regionu i dowodem na osłabianie rosyjskich wpływów w tej części świata.

Projekt korytarza Północ-Południe nie zagraża bezpieczeństwu energetycznemu, ani interesom państw członkowskich Unii Europejskiej. Kluczowe jest jednak pytanie, czy dojdzie w praktyce do jego efektywnej realizacji, zwłaszcza, że ta rozbudowa wymaga nakładów?

Po pierwsze, kluczowe jest zbudowanie gazociagu Baltic Pipe, a ponadto istotne jest tworzenie dalszych elementów infrastruktury przesyłowej na południu Europy, co wymaga nakładów finansowych. Tymczasem takowa de facto już istnieje, lecz zamiast uniezależnienia od Rosji, sprzyja większej zależności coraz większej ilości państw. Przykładem może być gazociag Gazela (zob. mapa 1). To uruchomione w 2013 roku połączenie, zapewnia tranzyt surowca z Saksonii do południowych landów Niemiec i dalej do Francji (Groszkowski, 2013). Inwestycja ta wpłynęła bezpośrednio na bezpieczeństwo energetyczne Czech, które ponad 64\% gazu importują z Rosji (reszta pochodzi z Norwegii i rynków spotowych). Połączenie czeskiej i niemieckiej sieci przesyłowej na granicy w Brandovie pozwoliło Czechom na dywersyfikację trasy dostaw rosyjskiego surowca i zapewniło alternatywę dla importu gazociagiem "Braterstwo" przez Ukrainę i Słowację (Net4Gas, 2017). To spowodowało, że więcej rosyjskiego gazu trafia do Czech przez Niemcy niż przez Słowację. W dłuższej perspektywie może to oznaczać, że również Słowacja będzie zaopatrywana w gaz z Nord Streamu przez Czechy.

Konkludując powyższe, budowanie gazowej infrastruktury przesyłowej w Unii Europejskiej nie jest zadaniem łatwym. Nie dotyczy to tylko kwestii regulacji prawnych, problemów związanych z technologią, czy uwarunkowań ekonomicznych, ale silnie związane jest z geopolityką. Przykłady inwestycji w rejonie Morza Bałtyckiego dobitnie pokazują jak trudno jest przezwyciężać partykularyzmy narodowe, budując wspólną strategię bezpieczeństwa energetycznego. 


\section{Podsumowanie}

Projekty infrastrukturalne w sektorze gazowym realizowane w rejonie Morza Bałtyckiego mają kapitalne znaczenie dla bezpieczeństwa energetycznego państw członkowskich UE.

Jak zaprezentowano w powyższym tekście, główną motywacją do tworzenia nowych połączeń są przede wszystkim partykularne interesy państw zaangażowanych w poszczególne inwestycje. Ich realizacja odbywa się z naruszeniem zasad lojalności i solidarności, które stanowią fundamentalne wartości Unii Europejskiej. Takie projekty jak Nord Stream I oraz Nord Stream II uderzają w bezpieczeństwo energetyczne regionu Europy Środkowo-Wschodniej. Wprawdzie połączenia gazowe, czyli „Jamał” oraz „Braterstwo” nadal istnieją, ale ich znaczenie jest współcześnie mniejsze, niż w epoce przed budową Nord Stream I, czy w kontekście planowanego zakończenia prac nad Nord Stream II. Dotychczasowe połączenia nie będą już miały dla Rosji kluczowego znaczenia z punktu widzenia dostaw surowca do Europy Zachodniej, natomiast będą miały kapitalne znaczenie jako potencjalne narzędzie nacisku na „stare państwa” tranzytowe, którym stosunkowo łatwo będzie można zagrozić zakręceniem gazowego kurka. Projekty te uderzają więc w poczucie bezpieczeństwa państw Europy ŚrodkowoWschodniej, ale również mocniej uzależniają UE od dostaw surowca z kierunku rosyjskiego.

Mówiąc o wpływie bezpośrednim projektów infrastrukturalnych na bezpieczeństwo tego regionu, należy wskazać przykład gazociągu Baltic Pipe (jako część korytarza Północ-Południe). Działania podejmowane przez państwa tego regionu należy uznać za przejaw pragmatyzmu w ocenie sytuacji międzynarodowej oraz przykład efektywnego działania na rzecz dywersyfikacji dróg i kierunków dostaw, co jest zgodne z europejską polityką energetyczną. Czy jednak ten projekt zakończy się sukcesem? Jest to uzależnione od postawy poszczególnych państw, które niejednokrotnie muszą wybierać między bezpieczeństwem energetycznym a efektywnością ekonomiczną. Nawet jeśli gaz rosyjski wydaje się tańszy i łatwej dostępny z uwagi na istniejącą infrastrukturę przesyłową, i tak należy myśleć o działaniach mających na celu zwiększenie niezależności. Czy jednak w tych państwach jest wystarczające poczucie solidarności regionalnej, aby doprowadzić do końca zainicjowane projekty współpracy? Czy też górę wezmą interesy partykularne każdego z nich i obawy przed narażeniem się rosyjskim partnerom? 
Rozbieżności w ocenie poszczególnych projektów w stolicach europejskich pokazują, iż bardzo trudno jest myśleć o sektorze energetycznym w kategoriach wspólnotowych. Zarówno w państwach Europy Zachodniej, jak również w Europie Środkowo-Wschodniej dominuje poczucie interesu narodowego i swoisty egoizm w podejmowaniu nowych projektów. Odnosząc się do hipotezy centralnej tego artykułu, wypada przyznać, że tam gdzie w grę wchodzi problem bezpieczeństwa energetycznego, tam kończy się poczucie europejskiej solidarności. Oczywiście na projektach infrastrukturalnych nie kończy się analizowane zagadnienie. Ważnym jego elementem jest również analiza modelu handlu gazem w Europie. Długoterminowe kontrakty gazowe, indeksowane do cen ropy nie odpowiadają podstawowym zasadom rynku. Sytuację można byłoby zmienić poprzez rynkowe wyznaczanie cen na hubach (ośrodkach handlu) i oparcia rynku na czynnikach popytu i podaży.

Praktyka pokazuje, że bezpieczeństwo energetyczne wiąże się z niemałymi nakładami i wysiłkami inwestycyjnymi. Warto jednak je czynić, aby zapewnić stabilne podstawy gospodarkom narodowym. Państwa Europy Środkowo-Wschodniej mają szanse i możliwości, przełamać monopol dostaw gazu z Federacji Rosyjskiej. Ważne jest jednak współdziałanie. Musi ono wziąć górę nad egoizmem i narodowymi partykularyzmami. Jeśli tak się stanie, Europa Środkowo-Wschodnia może znacząco przyczynić się do poprawy bezpieczeństwa energetycznego całej Unii Europejskiej, poprzez wzmocnienie więzi regionalnych oraz rozbudowanie sieci energetycznych.

\section{Bibliografia}

Barcz J. (2009), System prawny, porzadek instytucjonalny oraz proces decyzyjny w UE. Traktat o funkcjonowaniu Unii Europejskiej (wersja skonsolidowana), KONTRAST, Warszawa.

Boromisa A. M., Kałan D. (2013), Croatia: On the Southern Flank, w: North-South Gaz Corridor. Geopolitical Breakthrough in Central Europe, red. J. ĆwiekKarpowicz, D. Kałan, Polski Instytut Spraw Międzynarodowych, Warszawa, s. $36-41$.

Castel (du) V. (2014), La sécurité des approvisionnements énergétiques. Enjeux et défis pour l'Union européenne, L'Harmattan, Paris.

Chmaj M., Żmigrodzki M. (1996), Wprowadzenie do teorii polityki, Wydawnictwo Uniwersytetu Marii Curie-Skłodowskiej, Lublin.

Chodubski A. (2004), Wstęp do badań politologicznych, Wydawnictwo Uniwersytetu Gdańskiego, Gdańsk. 
Czaputowicz J. (2008), Teorie stosunków międzynarodowych. Krytyka i systematyzacja, PWN, Warszawa.

Dąbrowski T. (2014), Przełamujac bariery. Transformacja środkowoeuropejskich rynków gazu, Ośrodek Studiów Wschodnich, Warszawa.

Demkowicz A. (2010), Zewnętrzna polityka energetyczna Federacji Rosyjskiej, w: Bezpieczeństwo energetyczne Europy Środkowej, red. P. Mickiewicz, P. Sokołowska, Wydawnictwo Adam Marszałek, Toruń.

Gaz System (2017), Korytarz Pólnoc-Poludnie, http://www.gaz-system.pl/ourinvestments/integration-with-european-gas-tramsmission-system/north-south-gas-corridor/, 18.09.2017.

Groszkowski J. (2013), Gazociag Gazela połaczył Czechy z Nord Streamem, „Analizy" Ośrodek Studiów Wschodnich, https://www.osw.waw.pl/pl/publikacje/ analizy/2013-01-23/gazociag-gazela-polaczyl-czechy-z-nord-streamem, 14.11.2017.

Janusz P. (2013), Aktualna sytuacja na rynku gazu ziemnego - perspektywy, „Polityka Energetyczna", t. 16, z. 2, s. 33-52.

Kaczmarski M. (2010), Bezpieczeństwo energetyczne Unii Europejskiej, Wydawnictwo Akademickie i Profesjonalne, Warszawa.

Kajmowicz J., Rosjanie zwiększyli przesył gazu przez OPAL. Traci Ukraina i Stowacja, „Energetyka24.com”, 3.08.2017, http://www.energetyka24.com/639534,rosjanie-zwiekszyli-przesyl-gazu-przez-opal-traci-ukraina-islowacja, 14.09.2017.

Kaliski M., Sikora M. P., Sikora A. P. (2015), Kto napetni ukraińskie magazyny gazu?, „Polityka Energetyczna - Energy Policy Journal”, t. 18, z. 3, s. 61-74.

Kamiński J., Kaszyński P., Malec M., Szurlej A. (2015), Analiza zmian zużycia energii pierwotnej $w$ Polsce $w$ kontekście liberalizacji rynków paliw i energii, „Polityka Energetyczna - Energy Policy Journal”, t. 18, z. 3, s. 25-36.

Kochanek E. (2015), Gaz ziemny jako wspótczesny surowiec wykorzystywany w wojnie gospodarczej, w: Współczesna wojna handlowo-gospodarcza, red. J. Płaczek, Difin, Warszawa, s. 221-249.

Komisja Europejska (2000), Zielona księga: Ku europejskiej strategii bezpieczeństwa energetycznego, COM 2000 (769).

Komisja Europejska (2010), Komunikat: Priorytety infrastruktury energetycznej do roku 2020 i później. Plan dla zintegrowanej europejskiej infrastruktury energetycznej, COM (2010) 677.

Komisja Europejska (2010a), Energia 2020. Strategia na rzecz konkurencyjnego, zrównoważonego i bezpiecznego sektora energetycznego, COM (2010) 639.

Komisja Europejska (2013), Rozporządzenie delegowane Komisji nr 1391 z dn. 14.10.2013 zmieniajace rozporzadzenie Parlamentu Europejskiego i Rady (UE) nr 347/2013 w sprawie wytycznych dotyczqcych transeuropejskiej infrastruktury energetycznej $w$ odniesieniu do unijnej listy projektów będacych przedmiotem wspólnego zainteresowania, Dz. U. UE L 349 z 21.12.2013, s. 28-43. 
Komisja Europejska (2016), Decyzja Komisji C(2016) 6950 final z dnia 28.10.2016 w sprawie zmiany warunków wyłaczenia gazociagu OPAL z obowiazku stosowania zasad dostęu stron trzecich do sieci oraz regulacji taryfowej ustalonych $w$ dyrektywie 2003/55/WE.

Kryzia D. (2016), Poziom konkurencji na światowym rynku gazu ziemnego, „Polityka Energetyczna - Energy Policy Journal”, t. 19, z. 2, s. 47-64.

Łoskot-Strachota A. (2017), Gazociag OPAL: kontrowersje dotyczqce zasad wykorzystywania i kwestia bezpieczeństwa dostaw, Komentarze Ośrodka Studiów Wschodnich, 17.01.2017.

Mickiewicz P., Sokołowska P. (red.) (2010), Bezpieczeństwo energetyczne Europy Środkowej, Wydawnictwo Adam Marszałek, Toruń.

Muszyński M. (2015), Europejska solidarność - obowiqzek czy akt woli politycznej?, Ośrodek Analiz Strategicznych, https://oaspl.org/2015/09/07/europejska-solidarnosc-obowiazek-czy-akt-woli-politycznej, 7.09.2017.

Nagy S., Rychlicki S., Siemek J. (2009), Stan obecny i ewolucja stosunków gazowych Rosji z Uniq Europejska i Polska, ,Polityka Energetyczna”, t. 12, z. $2 / 2$.

Net4Gas (2017), Transmission system, http://www.net4gas.cz/en/transmission-system/, 21.09.2017.

Nord Stream 1 (2012), Secure Energy for Europe. The Nord Stream Pipeline Project, https://www.nord-stream.com/media/documents/pdf/en/2014/04/secure-energy-for-europe-full-version_245_20140417.pdf, 18.09.2017.

Nord Stream 2 (2017), Secure Gas Supply for Europe, https://www.nord-stream2. com/en/pdf/document/33/, 18.09.2017.

Nowacki M. (2010), Prawne aspekty bezpieczeństwa energetycznego w Unii Europejskiej, Wolters Kluwer, Warszawa.

Nutu A. O. (2013), Romania: No Direction in Gas Policy, w: North-South Gaz Corridor. Geopolitical Breakthrough in Central Europe, red. J. Ćwiek-Karpowicz, D. Kałan, Polski Instytut Spraw Międzynarodowych, Warszawa, s. 41-46.

Olkuski T., Szurlej A., Janusz P. (2015), Realizacja polityki energetycznej w obszarze gazu ziemnego, „Polityka Energetyczna - Energy Policy Journal”, t. 18, z. 2, s. 5-18.

Parlament Europejski, Rada (2013), Rozporządzenie Parlamentu Europejskiego i Rady (UE) NR 1316/2013 z dn. 11.12.2013 ustanawiajace instrument , Eqczqc Europe”, zmieniajace rozporzqdzenie (UE) $n$ r 913/2010 oraz uchylajace rozporzadzenia (WE) $n r$ 680/2007 i (WE) $n r$ 67/2010, Dz. U. UE L 348 z 20.12.2013, s. 129-171.

Regionalny Dyrektor Ochrony Środowiska, Obwieszczenie z dnia 28.04.2017: Decyzja o środowiskowych uwarunkowaniach dla realizacji przedsięwzięcia pn. „Budowa międzysystemowego gazociagu stanowiacego połaczenie systemów przesyłowych Rzeczpospolitej Polskiej i Republiki Stowackiej wraz z infrastrukturq niezbędna do jego obstugi-gazociag Strachocina-Granica RP'”.

Sangiovanni A. (2013), Solidarity in the European Union, „Oxford Journal of Legal Studies", vol. 33(2), s. 213-241. 
Schmidt V. A. (2010), La démocratie en Europe. L'Union européenne et les politiques nationales, La Découverte, Paris.

Sprawa T-883/16 R: Postanowienie prezesa Sądu z dnia 21.07.2017 - Polska/Komisja (Decyzja Komisji w sprawie zmiany warunków wyłaczenia spod przepisów Unii - Wniosek o zawieszenie wykonania), Dz. U. UE C 293 z 04.09.2017, s. $34-35$

Steinvorth U. (2017), Applying the Idea of Solidarity to Europe, w: Solidarity in the European Union. A Fundamental Value in Crisis, red. A. Grimmel, S. M. Giang, Springer, Heidelberg, s. 9-19.

Szurlej A. (2008), Możliwości konkurencyjności gazu ziemnego jako surowca do wytwarzania energii elektrycznej, „Gospodarka Surowcami Mineralnymi”, t. 24, z. 3, s. 327-338.

Tomaszewski K. (2014), Bezpieczeństwo energetyczne państwa, w: Trzy wymiary współczesnego bezpieczeństwa, red. S. Sulowski, M. Brzeziński, wyd. Elipsa, Warszawa, s. 202-219.

Tömmel I. (2009), Modes of Governance and the Institutional Structure of the European Union, w: Innovative Governance in the European Union. The Politics of Multilevel Policymaking, red. I. Tömmel, A. Verdun, Lynne Rienner Publishers Inc., Boulder-London, s. 9-23.

Traktat o funkcjonowaniu Unii Europejskiej (TFUE), wersja skonsolidowana, Dz. U. UE C 326 z dn. 26.10.2012.

Traktat o Unii Europejskiej (TUE), wersja skonsolidowana, Dz. U. UE C 326 z dn. 26.10.2012.

UOKiK (2016), Komunikat Biura Prezesa: Zastrzė̇enia wobec koncentracji - Nord Stream 2, 19.07.2016.

Vivid Economics (2016), Report prepared for DG ENER: Economic analysis of costs and benefits of approaches to enhancing the bargaining power of EU buyers in the wholesale markets of natural gas, https:/ec.europa.eu/energy/ sites/ener/files/documents/Final\%20report\%20-\%20with\%20disclaimer.pdf, 19.09.2017.

\section{The influence of infrastructure investments in the gas sector on energy security in Central and Eastern Europe}

\section{Summary}

Energy infrastructure is one of the determinants of energy security in modern states. This article addresses the issues of the natural gas sector and new infrastructure investments in the Baltic Sea Region. The text contrasts the theory of the process of European integration (the issues of solidarity and loyalty) with practice resulting from the pragmatic approach of EU member states to energy security issues. Taking the perspective of political science allowed a comprehensive analysis of the political conse- 
quences of the gas pipelines projects (Nord Stream I, Nord Stream II and Baltic Pipe) in Central and Eastern Europe. The article presents the play of interests surrounding these gas projects and points out that they are primarily determined by the particular interests of states (and companies) involved in the implementation of these projects.

Key words: energy security, natural gas, energy infrastructure, Central and Eastern Europe, European Union 